\title{
PROSPECTS OF IMPLEMENTATION OF THE AGRICULTURAL ENTERPRISE DEVELOPMENT STRATEGIES IN THE BIOENERGY MARKET
}

\author{
Dina Tokarchuk ${ }^{1}$
}

\begin{abstract}
The purpose of the paper is to identify and analyse strategic alternatives and conditions to create a strategy for the development of agricultural enterprises in the bioenergy market. Methodology. General scientific economic and mathematical methods as analysis, synthesis, abstraction, concretization and special methods as comparison, tabular, SWOT-analysis were used. Results of the study have shown that strategic development of agricultural enterprises will involve the development of technologies for biofuel production, using energy crops and waste from agricultural production. The factors of the external environment of the agricultural sector's choice of growth strategy in the bioenergy market were studied: natural and climatic, technological, economic, market, marketing, political and legal, infrastructural, educational and scientific, and ecological. Four possibilities of entering the bioenergy market (diversification) of agricultural enterprises (by 4 quadrants of the Ansoff matrix) were gradually analysed to select the optimal option that would take into account the characteristics of enterprises and guarantee economic growth at the lowest cost. Practical implications. Possibilities of realization of strategies of growth and/or diversification by the conditional agrarian enterprise have been estimated. According to the results of the analysis, the basic strategy of market penetration has been chosen. However, taking into account the possibilities of processing agricultural raw materials into biofuels, it is also advisable to choose a diversification strategy. The verification of the chosen strategy was carried out with the help of SWOT-analysis tools, which confirmed the possibility of the company entering the bioenergy market. Value/originality. Given the prospects of the strategy of diversification of the conventional agricultural enterprise in the direction of bioproduction, the conceptual provisions of this strategy have been proposed, which include three stages $(2022,2023-2024,2025-2027)$.
\end{abstract}

Key words: strategy, agricultural enterprise, market, biofuel, waste, bioethanol, biogas, solid biofuel.

JEL Classification: L10, Q42, Q57

\section{Introduction}

The organization of the production process based on maximum productivity of available production and resource potential and full production capacity is the key to successful and effective development of agricultural production in the changing market business environment and management of the main levers in ensuring sustainable economic development in the future. Successful implementation of these tasks will be facilitated by the development of a strategy for economic development of agricultural enterprises, which harmoniously combines the main aspects of planning and organization of production and economic processes with the most rational involvement and use at all stages of production of advanced resources, which is the basic for achieving effective development and the formation of sustainable competitive advantages. Therefore, the formation of development strategy and the development of practical recommendations for the correct choice of strategic guidelines that will best realize the human and resource potential for long-term effective operation of the enterprise, its economic growth and development are of great importance.

Modern market economy is characterized by instability and dynamism of socio-economic processes. To maintain the functioning and further development, the enterprises are forced to adapt

Corresponding author:

${ }^{1}$ Vinnytsia National Agrarian University, Ukraine.

E-mail: tokarchyk dina@ukr.net

ORCID: https://orcid.org/0000-0001-6341-4452

ResearcherID: L-7586-2018 
to constant changes in both external and internal environment. In turn, the choice of strategic direction in the management of economic entities ensures that they achieve their goals and adapt to new conditions.

In the context of ensuring further effective development of agricultural enterprises and solving the problem of reducing the energy dependence of the state on imported energy, it is important to effectively use the potential of non-traditional and renewable energy sources. Currently, it is impossible to consider strategic directions of development of agricultural enterprises without development of bioenergy potential.

Bioenergy potential of agricultural enterprises is understood by scientists as a set of all sources of natural or human-made agricultural or forestry origin for energy production (Ihnatenko, Marmul, 2017). These are primary resources in the form of special production of energy-intensive plant biomass (rapeseed, sunflower, corn, willow, etc.), secondary waste from agricultural, industrial and domestic production or processing of agricultural and wood raw materials (straw, seed husks, grape bushes and crop residues; trees, bark, sawdust, wood chips and other wood waste, cake, manure in animal husbandry). At the same time they provide not only production of bioethanol and biodiesel, but also wood pellets, granules or briquettes, and biogas.

Bioenergy potential can be considered the part of biological resources that can be considered as a source of renewable energy and the use of which does not reduce food security and does not disturb the natural ecological balance.

According to current economic approaches, the definition of "bioenergy potential of the agricultural enterprise" scientists consider as an orderly set of capabilities of the enterprise to effectively carry out the main activities on the basis of full reproduction of bioenergy resources through the functioning of energy exchange in controlled production and technological systems (Ihnatenko, Marmul, 2017).

In the context of rising energy prices, the importance of bioenergy potential in the structure of resource and production potentials of agricultural enterprises is growing.

The creation of own biofuel production becomes a source of additional competitive advantages for agribusiness entities, because along with cost savings compared to the use of mineral fuel, it increases the level of independence of the enterprise from the relevant resource markets and has a positive impact on its economic security and strategic advantages over competitors.

\section{Literature review}

Enterprise development is inextricably linked to strategy, strategic planning and management.

Strategy can be defined as a pattern of logical, consistent behaviour, which develops in the enterprise consciously or spontaneously, as the most important element of self-determination of the enterprise or organization. In this context, it is closely related to the characteristics and features of organizational culture, which, as a rule, has all its advantages and disadvantages, allows for a more thorough formulation of social strategies in general and elements of social trends in other types of strategies.

The organizational and managerial concept of strategy is related to competitive actions and methods of strategic activity in the enterprise.

There is currently no generally accepted and agreed definition of the term "strategy". According to H. Minzberg: "... each definition adds important elements to our understanding of strategy, prompting us to ask fundamental questions about organizations and their development in general..." (Minzberg, 1987). However, according to the analysis of literature sources, it can be argued that despite some differences in the constructive definitions proposed by the developers of the theory of strategic management, the ultimate goal of strategic development of the enterprise is to achieve its goals.

According to the views of A. Chandler on the classic strategic planning, strategy is the definition of the main long-term goals and objectives of the enterprise, the adoption of actions and allocation of resources necessary to achieve these goals (Chandler, 1962). On the one hand, this interpretation of "strategy" is based on the traditional approach to its definition as a special method of resource allocation between current and future activities, as A. Chandler notes that "...strategic alternative should be based on comparing the capabilities and resources of corporations accepted level of risk..." (Chandler, 1962). On the other hand, the main emphasis is on achieving goals in this definition.

The definition is based on such an approach: "...strategy is a general, comprehensive plan to achieve goals..." (Mescon, Albert, Khedouri, 2008). 
The identification of strategy and plan follows from game theory, where strategy is a plan of action in a specific situation, which depends on the actions of the opponent.

A. Thompson, a well-known specialist in strategic management, combines the planned principles of strategy with the behavioural aspects of the organization: "...strategy is a specific management action plan aimed at achieving the set goals. It determines how the organization will function and develop, as well as what business, competitive and functional measures and actions will be taken to ensure that the organization achieves the desired state..." (Tompson, Strickland, 2013).

In the fundamental work of $\mathrm{H}$. Ansoff "Strategic Management" the following concept of strategy is given: "...in essence, the strategy is a list of rules for decision-making, which the organization uses in its activities..." (Ansoff, 2007). H. Ansoff claims that an experienced business specialist will always be able to consider the success of the company this or that original strategy.

Some Ukrainian scientists consider the strategy as a set of long-term goals and a plan for the most efficient allocation of resources to achieve them (Pidvalna, Kozlovskyi, Hryniuk, 2015). L. Ye. Dovhan notes that the strategy is defined in a comprehensive approach, according to which the strategy is not only a means to achieve goals and mission, but also a program of enterprise operation in the external environment, interaction with competitors, customer satisfaction, realization of interests of owners and staff, strengthening competitive positions of the enterprise in the market (Dovhan, Karakai, Artemenko, 2009).

Butynets F. F. notes that the strategy is a set of rules necessary for decision-making, which the company uses in its activities (Butynets, Shyhun, 2004).

Despite the different approaches, all the above definitions do not contradict, but, on the contrary, complete each other, revealing the basic principles, methods and ways of forming and implementing strategy as a technology of enterprise management that ensures its most efficient operation and sustainable development in a constantly changing external business environment and internal organization of the enterprise.

The research of the peculiarities of the introduction of strategic planning in agriculture, in particular to the question of the strategy of economic development taking into account the bioenergy direction is made in the works of Berezyuk S. (Berezyuk, 2019), Pryshliak N. (Pryshliak, Tokarchuk, 2020), Kaletnik G. (Kaletnik, Honcharuk, Okhota, 2020), as well as in previous studies of the author (Tokarchuk, Pryshliak, Tokarchuk, Mazur, 2020), (Tokarchuk, 2016).

The importance and content of the research indicate not only the scientific interest in the problems of strategic ideology, but also the significant need of market participants to use their results in the practice of enterprise management. Despite the large number and diversity of research, there is no systemic approach that would combine existing paradigms based on a single methodology for planning the strategic development of enterprises in the bioenergy market.

The information base of the paper included scientific, monographic and periodical literature on the selected topic. General scientific economic and mathematical methods as analysis, synthesis, abstraction, and concretization have acquired special significance in solving the posed questions. Special methods as comparison, tabular method, SWOT-analysis were used.

\section{Results of the research and discussion}

Strategy is a long-term course of development of the firm, a way of achievement of the purposes which it defines for itself, being guided by own considerations within the limits of the policy. To develop a strategy, each company must be aware of the following important elements of its activities: mission; competitive advantages; features of business organization; markets where the firm operates; products (service); resource; structure; production programme; organizational culture.

Currently, the urgency of the problem of choosing a strategy for agricultural enterprises is gaining new meaning due to growing uncertainty in agricultural and related markets, the need to attract additional resources in increasing production or diversification, as well as scientific and technological progress that creates new opportunities for development and greening of fuel-energy.

General strategies of enterprises are divided into strategies of growth, stabilization (maintenance of competitive advantages) and reduction. The growth strategy is typical for those enterprises whose business is at an early stage or is developing rapidly. This strategy involves the selection of 
target segments, increased investment, $\mathrm{R} \& \mathrm{D}$ and innovation. The basic classification of growth strategies is known to be based on the Ansoff matrix. According to this matrix, companies can choose the strategy of market penetration, market development, product development or diversification.

Today the actual direction for the agricultural enterprises is diversification of activity in the direction of the organization of bioproduction. A number of natural, climatic, technological, economic, market and marketing factors should be taken into account to select a strategy for the growth and / or diversification strategy of agricultural enterprises in the bioenergy market. Among them there can be distinguished development of modern technologies of growing energy crops by enterprises; rising prices for traditional fuels; in the long run - increasing demand for biofuels from transport, as well as increasing the share of the electricity sector, which uses solid biomass and biogas as an energy resource, which will be determined by the relative sustainability of production (if the resource base is available).

The main political-legal factors are: state programs of bioenergy development; conducting a stable policy in the field of attracting investment; performance by the state of the function of protection of the internal market; development and maintenance of a sufficient level of competition between producers as the main driving force of scientific and technological progress in the bioenergy sector.

Educational and scientific factors include: introduction of principles and best practices of resource management in public management of bioenergy resources; development of education in the field of bioenergy (building on the basis of updated educational standards and programs to obtain the necessary competencies, knowledge and skills, creating a system of continuous training, significantly increasing the impact of bioenergy business on the formation of training programs); development of science in the field of bioenergy and development of experimental production base (including mechanisms of publicprivate partnership for creation of specialized centers of testing of technology of application of biotechnological products, formation of subprograms and separate actions for creation of pilot and research industrial enterprises).
Ecological factors are due to the growing environmental demands of consumers, as well as significant pollution of air, soil and water resources.

To clarify the type of enterprise growth strategy in the bioenergy market, it is first necessary to assess the potential sources of such growth. It is advisable to select them, assessing each of the possible key characteristics.

Each characteristic is assigned from one to three points, which will help assess the feasibility of using the strategy for the analysed product and the company's market. Putting scores in the Ansoff matrix allows to comprehensively assess each type of strategy and set priorities because the Ansoff strategy should be chosen so that the company operates on the principle of minimum costs and market resistance, so it is advisable to timely search for ways and factors of business growth in the existing market of available goods. After that it is necessary to search for opportunities to promote existing products in new markets. After achieving this result, the company should find options for selling a new product in the existing market and only in the last turn it is advisable for the company to diversify the business, which will reduce its risks. As the diversification strategy is the most risky, it should be resorted to only at the last moment, when the previous opportunities are exhausted.

This procedure for choosing a strategy according to the Ansoff matrix is standard. However, it should be taken into account that in the process of functioning of crop and livestock industries of agricultural enterprises, waste is generated (crop residues, husks, manure, etc.). The presence of such waste in sufficient quantities forms the bioenergy potential of the enterprise, which itself can be the basis for choosing a strategy of diversification with access to bioenergy markets.

Taking into account the peculiarities of agricultural enterprises and the possibility of their entry into the bioenergy market (diversification), it is necessary to analyze in stages four opportunities (4 quadrants of the Ansoff matrix) to ensure the growth of the enterprise with minimal costs. The sequence of such decisionmaking is shown in Figure 1.

The choice of any type of growth strategy involves the justification of clear criteria for assessing the effectiveness of the strategy (especially for the diversification strategy) with a planning horizon of three years. It should be 


\begin{tabular}{|c|c|c|}
\hline $\begin{array}{c}\text { Analysis of the } \\
\text { preconditions for } \\
\text { using the market } \\
\text { penetration strategy } \\
\text { and the possibility } \\
\text { of its } \\
\text { implementation }\end{array}$ & & 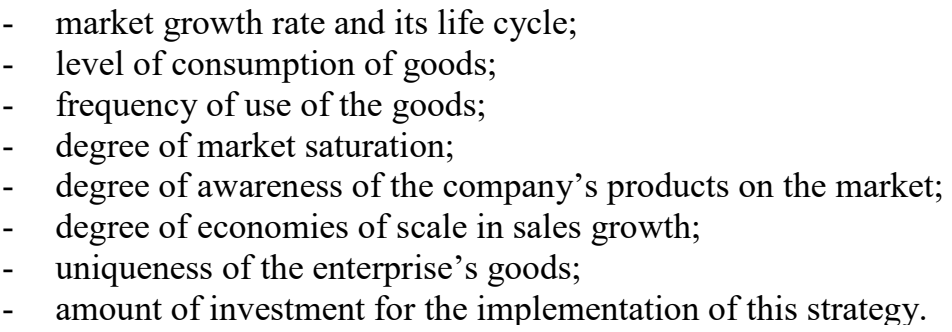 \\
\hline
\end{tabular}

\begin{tabular}{|c|c|}
\hline $\begin{array}{l}\text { The possibility } \\
\text { of implementing } \\
\text { a market } \\
\text { development } \\
\text { strategy }\end{array}$ & $\begin{array}{l}\text { - } \quad \text { success of the enterprise in this market; } \\
\text { - } \quad \text { level of competition in the new market; } \\
\text { - } \quad \text { strength of entry barriers in the new market; } \\
\text { - } \quad \text { growth rates of the new market; } \\
\text { - } \quad \text { uniqueness of the goods; } \\
\text { - } \quad \text { possibility of attracting investment. }\end{array}$ \\
\hline
\end{tabular}

\begin{tabular}{|c|}
$\begin{array}{c}\text { Ability to } \\
\text { implement a } \\
\text { product } \\
\text { development } \\
\text { strategy }\end{array}$ \\
\cline { 2 - 2 }
\end{tabular} \mid \begin{tabular}{ll|}
- & growth rates and size of the current market, as well as its life cycle; \\
- & competitiveness of current goods; \\
- & level of competition; \\
- & threats of entry of new players; \\
- & innovation of the current market; \\
- & level of updating the range and the emergence of new products from \\
key competitors in the current market.
\end{tabular}

\begin{tabular}{|c|c|}
\hline $\begin{array}{c}\text { Ability to } \\
\text { implement a } \\
\text { diversification } \\
\text { strategy }\end{array}$ & $\begin{array}{l}\text { - it is expedient to assess: the possibility of conducting large-scale } \\
\text { marketing research of the amount of crop residues and bioenergy } \\
\text { potential; the possibility of processing waste and / or bioenergy crops } \\
\text { into biofuels; interest of neighboring farms in cooperation in this area; } \\
\text { intensity of work with consumers; the possibility of attracting } \\
\text { investment and supply of additional raw materials. } \\
\text { - it is necessary to identify: prospects for the development of the } \\
\text { bioenergy market; business models of key competitors; tools and } \\
\text { methods of sales in the bioenergy market; volumes of own monetary } \\
\text { and time resources for entering the market and capturing the required } \\
\text { market share; financing, including the level of investment in new } \\
\text { technologies, equipment and product promotion. }\end{array}$ \\
\hline
\end{tabular}

Figure 1. Sequence of assessment of opportunities for agricultural enterprises to choose growth and/or diversification strategies (entering the bioenergy market)

noted that when assessing the prospects of enterprise strategies in the bioenergy market, it is advisable to take into account the growth rate of the market, as well as the financial and technical capabilities of the enterprise to process agricultural raw materials into biofuels.

According to the results of scientific research, Ukraine's agriculture has significant biomass potential. Straw of rye, wheat, barley, oats, millet, buckwheat, peas, rapeseed, soybeans, as well as corn and sunflower stalks are available for bioenergy production Energy potential is also possessed by enterprises that grow perennial plantations (energy potential of wood from pruning of fruit trees and vineyards), energy crops (rapeseed, energy willow, poplar, miscanthus, etc.), are engaged in animal husbandry (production of biogas from manure), etc. Thus, agricultural enterprises, which have a sufficient amount of land and grow the above crops, have the opportunity to apply a strategy of diversification.

As the example we have chosen a conventional Ukrainian agricultural enterprise with the area of agricultural land of 1,500 hectares and the average annual number of employees of 40 people. The company specializes in growing cereals and sunflower, has cattle, pigs, dairy cows ( 40 heads).

According to the results of the study, it is advisable to leave the basic strategy of market penetration for a conventional enterprise, 
but also, given the possibility of processing agricultural raw materials into biofuels, choose a diversification strategy to enter the bioenergy market, implementing a set of measures to influence potential consumers. Active work (communication) with the public and neighbouring farms, dissemination of relevant information on biofuels, including through the company's website, participation in exhibitions, etc. can be the tools of such influence.

It is advisable to verify the chosen strategy with the help of SWOT-analysis tools. SWOT-analysis is a process of establishing links between the most characteristic opportunities for the enterprise, threats, strengths (advantages), weaknesses, the results of which can be further used to formulate and select enterprise strategies. SWOT-analysis allows, on the one hand, to verify the hypotheses about the diversification of the enterprise on the bioenergy market, obtained from previous studies, and on the other hand, to systematize research results and formulate prerequisites for strategic alternatives in our case (Table 1).

\section{Table 1}

\section{SWOT-analysis of the strategy of diversification} of the conditional Ukrainian agricultural enterprise on the bioenergy market

\begin{tabular}{|c|c|c|c|}
\hline Factors & Weight & $\begin{array}{c}\text { Expert } \\
\text { assessment }\end{array}$ & $\begin{array}{c}\text { Weighted average } \\
\text { assessment }\end{array}$ \\
\hline \multicolumn{4}{|l|}{ Internal environment } \\
\hline \multicolumn{4}{|l|}{ Strengths $(\mathrm{S})$} \\
\hline $\begin{array}{l}\text { Availability of energy crops and waste potential for organic production } \\
\text { (crop and livestock industries) }\end{array}$ & 4.0 & 3.8 & 15.2 \\
\hline Updated technical base & 5.0 & 4.1 & 20.5 \\
\hline Existence of long-term lease agreements & 4.0 & 3.9 & 15.6 \\
\hline Existence of stable channels of distribution and promotion of agricultural products & 4.0 & 3.8 & 15.2 \\
\hline Level of autonomy and solvency & 4.0 & 4.7 & 18.8 \\
\hline Competitive pricing policy & 5.0 & 4.2 & 21.0 \\
\hline & & & 106.3 \\
\hline \multicolumn{4}{|l|}{ Weaknesses (W) } \\
\hline Narrow product range & 3.0 & 4.7 & 14.1 \\
\hline $\begin{array}{l}\text { Linear management structure, the need for interest of the head in the organization } \\
\text { of organic production }\end{array}$ & 5.0 & 3.2 & 16.0 \\
\hline Dependence on the supply of additional agricultural raw materials & 4.0 & 4.2 & 16.8 \\
\hline Insufficient use of marketing in activities & 4.0 & 4.0 & 16.0 \\
\hline Lack of experience in promoting bioenergy products & 3.0 & 4.0 & 12.0 \\
\hline Lack of own equipment for processing agricultural raw materials & 5.0 & 4.1 & 20.5 \\
\hline & & & 95.4 \\
\hline \multicolumn{4}{|l|}{ External environment } \\
\hline \multicolumn{4}{|l|}{ Opportunities $(\mathrm{O})$} \\
\hline Growing demand for bioenergy products & 5.0 & 4.7 & 23.5 \\
\hline State support in the field of organic production & 3.0 & 4.7 & 14.1 \\
\hline Access to new market segments & 5.0 & 4.1 & 20.5 \\
\hline Possibility to receive additional financing & 4.0 & 4.2 & 16.8 \\
\hline Rising prices for biofuels & 4.0 & 4.3 & 17.2 \\
\hline Improving technologies for obtaining biofuels from agricultural raw materials & 4.0 & 4.5 & 18.0 \\
\hline & & & 110.1 \\
\hline \multicolumn{4}{|l|}{ Threats $(\mathrm{T})$} \\
\hline $\begin{array}{l}\text { Increasing competition in the production of bioenergy crops } \\
\text { by other agricultural enterprises }\end{array}$ & 5.0 & 3.9 & 19.5 \\
\hline Adverse economic situation & 4.0 & 4.2 & 16.8 \\
\hline Prevalence of vertically integrated structures & 3.0 & 3.7 & 11.1 \\
\hline Rising taxes and customs duties and biofuels & 4.0 & 3.9 & 15.6 \\
\hline Inconsistency of legislation in the field of bioenergy & 4.0 & 4.3 & 17.2 \\
\hline Insufficient reputation in the new market & 4.0 & 4.1 & 16.4 \\
\hline & & & 96.6 \\
\hline
\end{tabular}


According to the results of the SWOTanalysis, the strategy of diversification of a conditional enterprise focuses on "strengths and opportunities" (weighted average score 106.3 and 110.1, respectively). This means that the verification confirmed the possibility of the company entering the bioenergy market. Given the prospects of the strategy of diversification of the conditional agricultural enterprise in the direction of bioproduction, we propose the conceptual provisions of this strategy (Table 2).

Stage I. As Ukraine is expected to introduce a mandatory share of biocomponents in fuel, it is projected that the number of enterprises engaged in the production of bioethanol and biodiesel will increase. The conditional agricultural enterprise should study the market of grain and oilseeds, and choose which enterprises are more economically profitable to sell products: food industry or biofuel production. With favourable market conditions, the company should establish contractual relations with biodiesel companies and bioethanol plants to supply them with raw materials. Cooperation on a tolling basis is possible: biofuel producers will compensate the cost of raw materials with products of their production, which the conditional enterprise will use instead of purchasing traditional fuel.

Stage II. Given the prospects for the production of biofuels by agricultural enterprises, the conditional agricultural enterprise must also establish bioproduction, using the available bioenergy potential:

- crop waste (grain straw, corn waste, sunflower) to produce pellets or briquettes;

- waste (by-products) of the livestock industry (cattle manure, pigs, sheep) to produce biogas.
On the one hand, this will help solve the problems of efficient waste management, especially in the livestock sector, which pose a potential threat to the environment if stored incorrectly. On the other hand, the company will receive biofuels, which can partially replace traditional energy sources. Thus, the conditional agricultural enterprise will be able to reduce the cost of purchasing fuel, electricity and heat, which will have a positive impact on the cost of final products. In addition to biofuels, the organization of biogas production will allow the studied company to obtain biofertilizers, replacing mineral fertilizers, the cost of which is quite high.

Stage III. In the future, the conditional enterprise should pay attention to such an energy crop as winter rapeseed. The organization of its cultivation with further use for the production of biodiesel will be the basis for the refusal to purchase diesel fuel and ensure energy autonomy.

In order to achieve the highest indicators of competitiveness and efficiency of biodiesel production, it is necessary to introduce production cooperation processes. As a result of mutually beneficial cooperation, the opportunities to use the potential of partners in the long run will increase. Cooperative production of biodiesel will contribute to the emergence of a synergistic effect that will exceed the simple amount of production capacity of individual enterprises of the agroindustrial complex.

\section{Conclusions}

The actual direction for the development of agricultural enterprises of Ukraine is diversification

Table 2

Strategy of diversification of activity of the conditional enterprise in the field of bioproduction

\begin{tabular}{|c|c|c|}
\hline Stages & Types of bioproduction strategy & Strategic measures \\
\hline \multirow{2}{*}{$\begin{array}{l}\text { Stage I } \\
2022\end{array}$} & \multirow{2}{*}{$\begin{array}{l}\text { Strategy for the supply of agricultural } \\
\text { raw materials to biofuel enterprises }\end{array}$} & $\begin{array}{l}\text { Calculation of the share of waste (by-products) of crop production, } \\
\text { which should be used for energy purposes }\end{array}$ \\
\hline & & $\begin{array}{l}\text { Implementation of a reasonable share of crop waste for biofuel } \\
\text { production enterprises, obtaining additional income }\end{array}$ \\
\hline \multirow{2}{*}{$\begin{array}{c}\text { Stage II } \\
2023-2024\end{array}$} & \multirow{2}{*}{$\begin{array}{l}\text { Implementation of the use of available } \\
\text { bioenergy potential for biofuel } \\
\text { production }\end{array}$} & $\begin{array}{l}\text { Organization of solid biofuel production from waste (by-products) of } \\
\text { the crop industry }\end{array}$ \\
\hline & & $\begin{array}{l}\text { Organization of biogas production from waste (by-products) of the } \\
\text { livestock industry }\end{array}$ \\
\hline \multirow[b]{2}{*}{$\begin{array}{c}\text { Stage III } \\
2025-2027\end{array}$} & \multirow[b]{2}{*}{$\begin{array}{l}\text { Increasing bioenergy potential and } \\
\text { diversification of biofuel production }\end{array}$} & Organization of winter rapeseed cultivation as an important energy crop \\
\hline & & $\begin{array}{l}\text { Organization of biodiesel production from rapeseed or organization } \\
\text { of joint production of this type of biofuel with other agricultural } \\
\text { enterprises, creating a biodiesel cooperative }\end{array}$ \\
\hline
\end{tabular}


of activity in the direction of the organization of bioproduction today. Taking into account the peculiarities of the functioning of enterprises in the agricultural sector and the possibilities of their entry into the bioenergy market (diversification), it is necessary to analyze in stages four possibilities: market penetration strategies; market development strategies; product development strategies; diversification strategies.

According to the results of research a diversification strategy (with access to the bioenergy market) is the most profitable for a conventional Ukrainian agricultural enterprise. Verification by the method of SWOT-analysis confirmed the possibility of the company to enter the bioenergy market. The implementation of the strategy of diversification of activities for a conventional agricultural enterprise in the field of bioproduction in three stages is proposed:

Stage I - the strategy of supplying agricultural raw materials to enterprises producing biofuels;

Stage II - implementation of the use of available bioenergy potential for biofuel production (organization of biogas and solid biofuel production from agricultural waste);

Stage III - increasing the bioenergy potential and diversification of biofuel production (organization of winter rapeseed cultivation and its processing into biodiesel within the enterprise or biodiesel cooperative).

\section{References:}

Ansoff, H. (2007). Strategic Management. Palgrave Macmillan.

Berezyuk, S., Tokarchuk, D., \& Pryshliak, N. (2019). Resource Potential of Waste Usage as a Component of Environmental and Energy Safety of the Sate. Journal of Environmental Management and Tourism, vol. 10(5), pp. 1157-1167.

Butynets, F. F., \& Shyhun, M. M. (2004). Modeli i metody pryiniattia rishen v analizi ta audyti [Models and methods of decision making in analysis and audit]. Zhytomyr: ZhDTU. (in Ukrainian)

Chandler, A. D. (1962). Strategy and Structure Chapters in the History of the American Industrial Enterprises. Cambridge. MA: MIT Press.

Dovhan, L. Ye., Karakai, Yu. V., \& Artemenko, L. P. (2009). Stratehichne upravlinnia [Strategic manadement]. Kyiv: Tsentr uchbovoi literatury. (in Ukrainian)

Ihnatenko, M. M., \& Marmul, L. O. (2017). Formuvannia ta rozvytok bioenerhetychnoho potentsialu ahrarnykh pidpryiemstv na zasadakh kontrolinhu [Formation and development of bioenergy potential of agricultural enterprises on the basis of controlling]. Infrastrkutura rynku - Market infrastructure, vol. 13. Retrieved from: http://www.market-infr.od.ua/uk/13-2017 (accessed 10 April 2021).

Kaletnik, G., Honcharuk, I., \& Okhota, Yu. (2020). The Waste-Free Production Development for the Energy Autonomy Formation of Ukrainian Agricultural Enterprises. Journal of Environmental Management and Tourism, XI, no. 3(43), pp. 513-522.

Minzberg, H. (1987). The Strategy Concept II: Ahother Look at Why Organizations Need Strategies. California Managment Rev.

Mescon, M. H., Albert, M., \& Khedouri, F. (2008). Osnovy menedzhmenta: uchebnoe posobye (Trans., 3th ed.). Moscow: Vyliams. (in Russian)

Pidvalna, O. H., Kozlovskyi, S. V., \& Hryniuk, R. F. (2015). The sustainability of agricultural sphere of the region as a factor in the economic development of Ukraine. Regional innovations, vol. 1, pp. 22-31.

Pryshliak N., \& Tokarchuk D. M. (2020). Socio-economic and environmental benefits of biofuel production development from agricultural waste in Ukraine. Environmental \& Socio-economic Studies, vol. 8(1), pp. 18-27.

Tokarchuk, D. M., Pryshliak, N. V., Tokarchuk, O. A., \& Mazur, K. V. (2020). Technical and economic aspects of biogas production at a small agricultural enterprise with modeling of the optimal distribution of energy resources for profits maximization. INMATEH -Agricultural Engineering, vol. 61(2), pp. 339-349.

Tokarchuk, D. M. (2016) Stratehichni napriamy vyrobnytstva biopalyva silskohospodarskymy pidpryiemstvamy Ukrainy [Strategic directions of biofuel production by agricultural enterprises of Ukraine]. Ekonomika. Finansy. Menedzhment: aktualni pytannia nauky i praktyky - Economy. Finances. Management: current issues of science and practice, vol. 7, pp. 18-26. (in Ukrainian)

Tompson, A., \& Strickland, A. J. (2013). Strategic Management: Concepts and Cases. Mcgraw-Hill; 13th edition. 